Sondes Research Institute has always endeavoured to supply the research tools and the trained staff which such firms lack. All rights in any discoveries made in a project are automatically assigned to the sponsor, so that the Institute may be regarded as the research department of the sponsor for the duration of the project. Experience at Sondes Place confirms the difficulty of liaison with industrialists who are unable to define their own problems in terms which the technical man can understand, and also the backwardness of small firms in appreciating the contribution science can make to improving productivity.

Technical Graduates in the British Armed Services

IN written answers to Parliamentary questions on November 22, the Minister of Defence, Mr. H. Macmillan, stated that about 940 uniformed personnel at present employed on instructional duties in the Fighting Services hold degrees in science, including mathematics and engineering, the average annual intake for this purpose into the Royal Navy and the Royal Air Force together during the past three years being about 165 . In addition, some 120 civilian science or engineering graduates are employed on instructional duties with all three Services, with an average annual intake of about ten during the past three years. Some 2,860 civilian science and engineering graduates are employed on research and development by the Service and supply departments, the average annual intake during the past three years being about 185. Science graduates are not recruited into the Services specifically for research and development duties, but about 110 uniformed personnel holding degrees in science, including mathematics and engineering, are in addition employed on research and development for the Services.

\section{J. A. Gilruth and his Influence on Commonwealth Livestock Industries}

This year the Macrossan Memorial Lecture was given at the University of Queensland by Sir Ian Clunies-Ross, chairman of the Commonwealth Scientific and Industrial Research Organization, Australia, who chose as his subject "John Anderson Gilruth : the Influence of his Life and Work on the Development of the Livestock Industries of the Commonwealth". Gilruth combined a forceful personality with true administrative and scientific ability. After training as a veterinarian at Glasgow, he spent seventeen years in New Zealand, where he built up what was probably the best government veterinary service in the British Commonwealth. Sir Ian considers this service one of the chief reasons why New Zealand achieved such a high reputation for exports of lamb and dairy produce. In 1909 Gilruth was appointed the first professor of veterinary science in the University of Melbourne, where he established the first five-year veterinary course in the British Commonwealth, if not in the world. The last and equally fruitful phase of his career started in 1929, when he was appointed chief of the Division of Animal Health of the then newly formed Council for Scientific and Industrial Research, now the Commonwealth Scientific and Industrial Research Organization. His sound judgment and planning have been reflected in the output of important research by the Organization in nutrition and infectious diseases, much of it fundamental in nature. His strong personality and original mind were responsible for the initiation and successful pursuance of a number of investigations that have yielded far-reaching results. Sir Ian then reviewed the achievements of Australian scientific workers in these fields and closed by pointing to some major problems still confronting the further development of Australia's agricultural industryproblems that offer a fascinating challenge to the best scientists that the country can produce.

\section{Indian Journal of Fisheries}

THE first issue of a new journal, the Indian Journal of Fisheries (1, Nos. 1 and 2; May 1954; pp. $416+8$ plates; Rs. 7.8 net), published by the Ministry of Food and Agriculture of the Government of India, New Delhi, has recently appeared, and the welcome that one would normally accord to a new periodical devoted to scientific research in India is all the warmer for one that deals with questions likely to increase food supplies. The joumal deals with fisheries research in Indian and adjacent waters - freshwater, lacustrine and salt water-and there are papers on plankton, algae, molluses, crustaceans and fish. In all cases attention is given to the practical aspect of ensuring a continuation and improvement of the fish supply, the spewning and growth of fish being carefully considered. A detailed description is given of the Central Marine Fisheries Station, Mandapam Camp, Southerm India, and this account must arouse envy in the hearts of fishery research workers in Europe, for there are twenty-three scientific officers, twenty-two research assistants and fourteen fishery survey assistants, in addition to the normal administrative staff. There are also subsidiary research stations, notably in Calicut and Karwar, and an inland fisheries research station has. been established in Calcutta. There are lists of the publications issued at Mandapam and Calcutta. The Government of India is to be heartily congratulated, since in this issue of the new journal practically no problem connected with the fisheries is overlooked or neglected.

\section{Fisheries of Lake Chilka in Southern India}

ChILKa Lake, which is situated on the east coast of India near Puri in the State of Orissa, is really a lagoon, for it communicates with the open sea by a narrow channel fourteen miles long. In the rainy season the area is 450 square miles, shrinking to 350 square miles in dry weather. It is very shallow, varying in the dry season from 8 to $4 \mathrm{ft}$. in depth. The salinity varies from practically fresh water to a high salinity near the sea entrance. Consequently, there is a remarkable fauna, both of fish and invertebrates. The total number of species of fish known in the Lake is 138. Large quantities of carp fry drift down into the Lake during floods and are utilized for stocking freshwater tanks. The shallowness of the Lake makes fishing comparatively easy, and the bulk of the catches goes by rail to Calcutta. A full description of the methods of fishing is given in the paper by $\mathrm{S}$. Jones and K. H. Sujansingani in the first volume of the new Indian Journal of Fisheries (see above). The chief food fish are mullets, clupeoids, catfishes, sciosnoids, perches and bekti, and the yield per acre (both fresh and dried fish) amounted in the years 1948,1949 and 1950 to $34 \cdot 48,31 \cdot 58$ and $29 \cdot 80 \mathrm{lb}$., respectively. Since the Lake is an uncultivated piece of water and more than a fourth of it is too shallow to support a good fishery, these totals must be considered satisfactory. The authors recommend the abolition of the present zemindari (landlord) system and the transfer of the fishing rights to the State. 